\title{
Anglicisms in Italian and Albanian Language in the Field of Telecommunication and Informatics
}

\author{
Isida Shehu \\ Polytechnic University of Tirana \\ Faculty of Mechanical and Physical Engineering \\ Centre of Foreign Languages
}

\section{Doi:10.5901/mjss.2013.v4n10p689}

\begin{abstract}
The two branches, that of telecommunication and informatics, are lately introduced in Albania. Since these branches are largely developed in English speaking countries, the terms used even in Albanian textbooks are English ones. This phenomenon in also viewed in Italian language. But apart from what is mentioned above, another reason why anglicisms have entered both these languages is because of the lack of native words, thus Italian and Albanian words for certain items, devices or services in these fields of study. An approach of anglicisms that function as terms in both languages. How much do they differ? E.g. both languages use the term 'plotter', 'baseband' but there are cases where one of the languages uses a native term instead of an anglicism. For the English term 'pointer', the Italian equivalent is 'puntatore', whereas in Albanian it is used either 'pointer' or 'pikëzues'. For the term 'jacket', in Italian it is used the term 'custodia' whereas in Alabanian it is used the English term' jacket' or the Albanian equivalent 'këllëf' 'mbulesë'.
\end{abstract}

\section{History of anglicisms in Albanian and Italian language.}

Foreign words have entered Albanian language, a member of the Indo-European family and one of the oldest languages in Balkan, hundreds of years ago. Many words were loaned from Old Latin and ancient Greek, some of which have been totally absorbed and are nowadays part of the Albanian lexicon. Other words were borrowed from Turkish and Slavic language. Later in the $20^{\text {th }}$ century Albanian was influenced by French, Italian and English language. Loan words are encountered in the spoken and written language as well since the borrowings started as Prof. J.Thomai puts it $(2006 ; 257)$ in the $3^{\text {rd }}$ century BC, when Greek colonies settled in the Illyrian territory and they continue to date. Loan words maybe either simple words or term. In this paper I will mainly focus on words that function as terms.

Regarding English loan words nowadays, they are widely encountered in media, politics and technology. According to R.Këcira $(2009 ; 9)$ the areas where anglicisms are widely encountered are ranged as below: media, politics and economy, modern warfare, science and technology, commerce etc. Prof. J.Thomai writes in his book 'Lexicology of Albanian Language' (2006;250) that English words entered Albanian language in the 1920s. R. Këcira's monograph 'Anglicisms in Albanian; A language contact phenomenon' provides facts about the existence of anglicisms either as terms or simple words in Albanian, since 1920s. The data she used was the collection of the newspaper published in Albania 'Laboremus' in the 1920s, four dictionaries and a three month collection of the newspaper Gazeta Shqiptare. Some of the anglicisms used in the corpora above mentioned are: 'mottoja' today used as (motoja), 'campion' (kampion), 'kollegj' (kolegj), 'flanella' (fanela), 'alcohol' (alkol), 'chassin' (shasi), 'refrigerator' (frigorifer), 'chequesh' (ceqesh) etj.

As far as anglicisms in Italian is concerned, Satu Pirkkalainen (2002:5) points out that some English words entered Italian in the $19^{\text {th }}$ century but in the 1930s the Italian government under the dictation of Mussolini tried to substitute all foreign words with Italian ones even though later it was impossible to prevent these words from entering Italian language due to the Anglo-American culture. Maria Leticia Mariani (2011) in her article 'Itanglese: Gli anglicismi nel linguaggio quotidiano'writes that the number of Anglicisms in Italian is approximately 6000, most of which entered Italian after the Second World War.

For this paper I consulted textbooks in Italian in the field of informatics and telecommunication such as 'L'informatica'- P.Bishop; 'Reti di telecommunicazione'- A.Roveri and 'Calcolatori Eletronici'- R.Cuchiara and Albanian textbooks, 'Komunikimet me fibra optike' R. Mitrushi 'Informatika 1' I.Ninka, N.Frashëri, E.Arkaxhiu. Some of the anglicisms I encountered in these books were; input, personal computer, bus, plotter, cluster, pointer, cicli di wait, flipflop, programazione top-down etc. The aim of this paper is to spot some of the anglicisms in the Albanian and Italian textbooks used in the field of telecommunication and informatics and see how they differs from one language to another. 


\section{Reasons for borrowing}

The main reason why borrowings occur is because there is a lack of native words in naming or designating certain phenomena, devices, services etc. Informatics and telecommunication are relatively new branches of study in Albania. As such it is sometimes difficult to designate certain devices, items or services that are unknown to us. When reading certain text books in Albanian in the field of informatics and telecommunication, you encounter a lot of foreign words, mainly English ones. Albanian authors, field specialists or professors do not have or can not find an Albanian term and thus they resort to English ones (since the bibliography used is mainly English). But this is not the only case. There are cases in which the Albanian term exists but it's not used, either because it may be unknown to the author or maybe its easier for him/her to use a foreign word instead of searching or risking to use an Albanian equivalent.

\section{Anglicisms approach in Albanian and Italian textbooks of telecommunication and informatics.}

Below it is given a list of some anglicisms used in both languages. There are cases in which both Italian and Albanian language use only the English term because there isn't any equivalent in neither language such as cluster, plotter (in Albanian it is written with a single 't', ploter ), hardware (even though in Albanian it is sometimes written 'harduer' because it has undergone changes under the Albanian phonetic system $\left.{ }^{1}\right)$, etj.

Table 1.

\begin{tabular}{|l|l|l|l|}
\hline & English term & Albanian & Italian \\
\hline 1. & Plotter & Ploter & Plotter \\
\hline 2. & Bus & Bus & Bus \\
\hline 3. & Cluster & Cluster & Cluster \\
\hline 4. & Hardware & Harduer & Hardware \\
\hline
\end{tabular}

Sometimes both languages use the anglicism and a respective equivalent term for example; in Albanian texts you encounter 'input' and 'hyrje; 'pointer' and 'pikëzues'; 'çip' and 'qark integrues' etj.

\begin{tabular}{|l|l|l|}
\hline & English term & Albanian \\
\hline $\mathbf{1 .}$ & Input & Input/ hyrje \\
\hline $\mathbf{2}$ & Pointer & Pointer/pikëzues \\
\hline $\mathbf{3 .}$ & Chip & Cip/ qark integrues \\
\hline $\mathbf{4 .}$ & Output & Output/dalje \\
\hline $\mathbf{5 .}$ & File & File/faj//skedar \\
\hline $\mathbf{6 .}$ & Buffer & Bafer/ ndërmemorie \\
\hline $\mathbf{7 .}$ & Software & Softuer/ programet e kompjuterit \\
\hline $\mathbf{8 .}$ & Clock & Klok/takt/gjenerator I taktit \\
\hline $\mathbf{9 .}$ & Flag & flag/ tregues/indicator/marker \\
\hline $\mathbf{1 0 .}$ & Broadband & Broadband/brezgjere \\
\hline $\mathbf{1 1 .}$ & Flip-flop & Flip-flop /shilarës/multivibrator bistabël \\
\hline
\end{tabular}

Table 2

In Italian textbooks both terms are used 'output' and 'emissione'; 'input' and 'ingresso'. See table 3.

Table 3

\begin{tabular}{|l|l|l|}
\hline & English term & Italian \\
\hline 1. & Input & Input/ ingress \\
\hline 2. & Output & Output/emission \\
\hline 3. & Polling & Polling/(technica d') interrogazione \\
\hline 4. & Forwarding & Forwarding/anticipazione \\
\hline
\end{tabular}

${ }^{1}$ Some anglicisms in Albanian are not used in their English phonetic or grammatical form, because they change under the Albanian phonetic system, but there are many English words that preserve their English form such as the term 'cluster' which in Albanian, should be written 'klaster', the term 'output' is not written in Albanian textbooks as 'autput' etc. 
In the table below I have listed some anglicisms encountered in the Albanian and Italian textbooks and where possible an Albanian and Italian equivalent which either stands next to the anglicisms or is used alone.

\section{List of Anglicisms encountered in some Albanian and Italian textbooks of informatics and telecommunication}

\begin{tabular}{|l|l|l|l|}
\hline No. & \multicolumn{1}{|c|}{ English term } & \multicolumn{1}{|c|}{ Albanian } & \multicolumn{1}{c|}{ Italian } \\
\hline 1 & Input & Input/ hyrje & $\begin{array}{l}\text { Input/ (operazione d') } \\
\text { ingresso }\end{array}$ \\
\hline $\mathbf{2}$ & Output & Output/ dalje & $\begin{array}{l}\text { Output/emissione/ } \\
\text { (operazione d') uscita }\end{array}$ \\
\hline $\mathbf{3}$ & File & File/faj//skedar & File \\
\hline $\mathbf{4}$ & Buffer & Bafer/ ndërmemorie & Buffer \\
\hline $\mathbf{5}$ & Plotter & Ploter & Plotter \\
\hline $\mathbf{6}$ & Software & Softuer/ programet e kompjuterit & Software \\
\hline $\mathbf{7}$ & Hardware & Harduer & Hardware \\
\hline $\mathbf{8}$ & Personal computer (pc) & Kompjuter personal (pc) ${ }^{2}$ & Personal computer (pc) \\
\hline $\mathbf{9}$ & Flag & Flag/ tregues/indicator/marker & Flag \\
\hline 10 & Interface & Ndërfaqe & Interface/ interfaccia \\
\hline 11 & Pointer & Pointer/pikezues & Puntatore \\
\hline 12 & Floppy disc & Flopi disk/diskette/ disk I bute & Dischetti flessibili \\
\hline 13 & Hard copy & Hard copy & Coppia fisica \\
\hline 14 & Forwarding & - (gjuhë e folur, forword-oj) & Anticipazione \\
\hline 15 & Polling & Polling & (technica d') interrogazione \\
\hline 16 & Bus & Bus & Bus \\
\hline 17 & Chip & Cip/ qark integrues & Chip \\
\hline 18 & Clock & Klok/takt/gjenerator I taktit & Temporizattore \\
\hline 19 & Cluster & Cluster & cluster \\
\hline $\mathbf{2 0}$ & Broadband & Broadband/brezgjere & Larga banda \\
\hline $\mathbf{2 1}$ & Jacket & Këllëf/mbulesë & Custodia \\
\hline $\mathbf{2 2}$ & Data bank & Bankë e të dhënave & Banco dati \\
\hline $\mathbf{2 3}$ & Mouse & Maus/ mi & Mouse \\
\hline $\mathbf{2 4}$ & Flip-flop & Flip-flop /shilares/multivibrator bistabël & Flip-flop \\
\hline & & & \\
\hline
\end{tabular}

\section{Table 4}

\section{Conclusions}

As many European languages, Albanian and Italian language can not escape the influence of English words/terms since it is an international language. It is a language spoken in the most developed countries where technological and scientific developments are of a high rate. Anglicisms are nowadays widely studied because they are present in many other languages such as French, Spanish, Italian, German, Albanian etc, even though they differ in usage from one recipient language to another because sometimes they undergo the phonetic, grammatical rules of the recipient language and the degree of assimilation differs. Such is the case of anglicisms in Albanian and Italian language dealt with above where it seems that anglicisms are not always used in the same way. Sometimes the two languages take the English terms as it is in English and do not make any changes to it, sometimes they adjust it to their phonetic, grammatical, morphological system and sometimes they try to substitute the English term with a native one. As far as their attitudes to anglisisms is concerned, I must say that the two languages are opened to foreign words, in our case English ones, even though there must be rules that control foreign words entrance and usage.

${ }^{2}$ The abbreviation ' $p c$ ' used in English and Italian is used in Albanian as well even though the Albanian equivalent for 'personal computer' is 'kompjuter personal'. 


\section{References}

Akademia e Shkencave te Shqiperise, Fjalor I Gjuhës Shqipe, 2006

Anastasio, Vittorio. Dictionary of Informatics, 1991

Caka, Nebi. Fjalori anglisht-shqip,shqip-anglisht I Informatikës, 2006

Duro, Agron. Studime Gjuhësore, 2012

Illingworth, Vallerie .Dictionary of Electronics,1998

Këcira, Rajmonda. Anglicisms in Albanian: A Language Contact Phenomenon, 2009

Tomcini, Arif. Fjalor Anglisht-Shqip I Radioelektronikës,2004

Thomai, Jani. Leksikologjia e Gjuhës Shqipe, 2006 